\title{
PRELIMINARY RESULTS REGARDING THE BEHAVIOUR OF SOME NEW APRICOT CULTIVARS IN BUCURESTTI AREA
}

\author{
F. Stănică1 ${ }^{\text {, A.C. Butcaru1 }}{ }^{*}$, C.A. Mihai' ${ }^{1}$, I.M. Florea1 ${ }^{1}$ and D. Șerban1 \\ 1Faculty of Horticulture, University of Agronomic Sciences and Veterinary Medicine, \\ Bd. Mărăști, nr. 59, 011464, Bucharest, Romania \\ *Corresponding author email: anabutcaru@gmail.com
}

\begin{abstract}
The study presents the behaviour of 28 apricot cultivars planted in 2017 in the Experimental Field of the Faculty of Horticulture within the University of Agronomic Sciences and Veterinary Medicine of Bucharest. The foreign cultivars grafted on Myrobalan 29C, Saint Julien A and GF 677, were planted at $4.5 \times 1.5 \mathrm{~m}$ and $3.5 \times 2.0 \mathrm{~m}$ for Parallel $U$ and respectively, $3.5 \times 2.0 \mathrm{~m}$ for Trident canopy. Trees vegetative growth was evaluated by analysing the trunk cross section, tree height, fruiting branches number and length. First fruit yield was heighted and the productivity index was calculated. The results show differences in growth correlated with the canopy, cultivars and used rootstocks. Correlations between analysed parameters are presented. As a conclusion, the differences between the two canopies, Parallel $U$ and Trident, using different types of rootstocks show their influence on the annual vegetative growth and on apricot trees productivity. Some preliminary conclusions can be drawn regarding the advantages and disadvantages of using the two canopies in apricot orchards.
\end{abstract}

Key words: Armeniaca vulgaris, rootstocks, canopies, correlations.

\section{INTRODUCTION}

Apricot is an important fruit crop for the southern and western regions of Romania with a long tradition of cultivation (Bălan et al., 2008). Several breeding programs are active in Europe (Asma, 2012; Audergon et al., 2012; Auvinet et al., 2020; Bassi and Foschi, 2020; Bălan, et al., 2008; Egea et al., 2012;Krška and Vachůn, 2016; Nesheva et al., 2020; Milatović et al., 2012; Oprița et al., 2020; Suran and Skřivanová, 2020; Topor et al., 2010) and worldwide (Dejampour, 2012; Liu et al., 2012; Gouble et al., 2020; Xue et al., 2020) so, there is a constant interest to promote and introduce new cultivars. In order to evaluate the behaviour of new genotypes in different cultivation area (Gouble et al., 2020), field trials are essential and the results over few testing years need to be used when the introduction of a new cultivar is decided (Stănică et al., 2010; Stănică and Eremia, 2014; Tabakov and Yordanov, 2012; Zaman et al., 2018). In fruit trees, the field performances of a new cultivar, regarding the tree vigour, growth, yield and fruit quality, besides its genetic heritage, are essentially influenced by the rootstock (Duval et al., 2012; Krška et al., 2012; Tabakov and Yordanov, 2012), planting system and tree canopy (Stănică et al., 2012; Matei et al., 2013; Stănică and Eremia, 2014; Negru, 2019; Negru and Peșteanu, 2019). Besides the traditional Open Vase canopy, used in classical low-density plantings, in the modern commercial apricot orchards, canopies with one, two or three vertical axes are more diffused (Meland, 2001; Musacchi, 2008; Stănică, 2019. The vertical axe canopies have some important 
advantages (Robinson et al., 2011; Dorigoni et al., 2011; Stănică, 2019), being closer to the natural tree growth tendency (Lauri et al., 2011), easy to conduct and maintain, and giving the possibility of annual renewal of the fruit shoots (Neri et al., 2010).

The present paper presents some preliminary results regarding the behaviour of 28 cultivars, most of them new introduced to Romania, cultivated in Bucharest on two canopies Parallel $U$ and Trident on different rootstocks.

\section{MATERIALS AND METHODS}

In 2017, at the Experimental Field of the Faculty of Horticulture within the University of Agronomic Sciences and Veterinary Medicine of Bucharest, 28 apricot cultivars have been planted. Most of the cultivars were newly introduced to Romania: Congat, Primando, Primaya, Rubista, Wonder Cot, Lady Cot, Delice, Lily Cot, Milord, Swired, Mikado, Lido, Med Flo, Flopria, Faralia, Farely, Farbali, Fartoli, Farbela, Anegat, Farlis, Farclo, while others: The Best of Hungary, Bergeron, Vitillo, Boccuccia Liscia, Portici, Pisana, are already tested and known. The apricot cultivars were grafted on three rootstocks: GF677, Mirobolan 29 and Saint Julien A. Two canopies and two planting systems were tested: Parallel U, planted at $4.5 \times 1.5 \mathrm{~m}$ and $3.5 \times 2.0 \mathrm{~m}$ and Trident, planted at $3.5 \times 2.0 \mathrm{~m}$. Trees were conducted on a four wires trellis system with $4.5 \mathrm{~m}$ high concrete poles. On the row, drip irrigation was provided by a drip line with $0.5 \mathrm{~m}$ between self-compensated ( $2 \mathrm{l} /$ hour) drippers. Between the rows, the soil was kept grass-covered with regular mowing. Tree vigour was evaluated by measuring tree height and axis length, trunk cross section (TCS) and the total annual shoots vegetative growth.

In the same time, tree productivity was expressed by the yield expressed on $\mathrm{kg} /$ tree and $\mathrm{t} / \mathrm{ha}$, and by the productivity index $-\mathrm{kg} / \mathrm{cm}^{2} \mathrm{TCS}$.

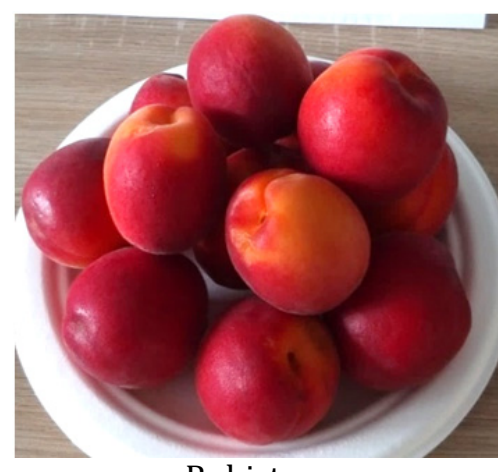

Rubista

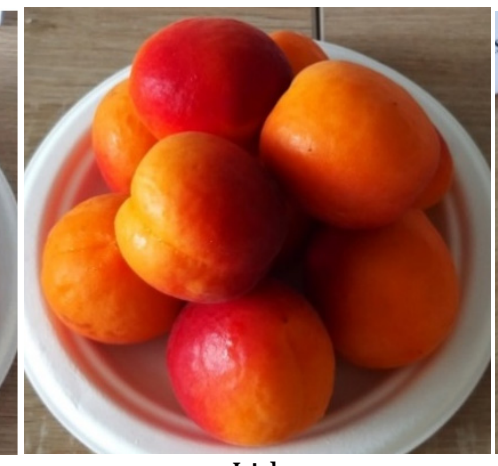

Lido

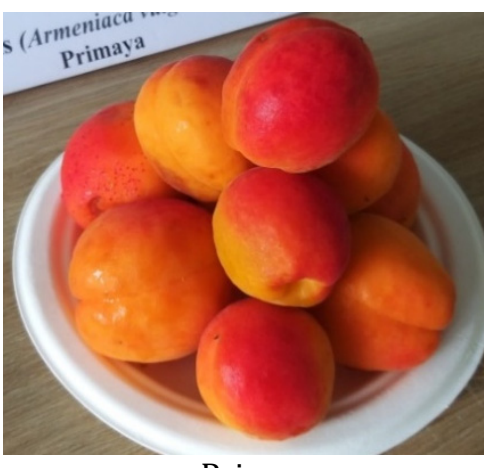

Primaya

Figure 1. Some of the tested apricot cultivars: Rubista, Lido and Primaya

\section{RESULTS AND DISCUSSIONS}

\section{Tree vigour}

Tree height was both influenced by cultivar and rootstock. As one can see in the Figure 2 ( $a$ and $b$ ), in the first year after planting, most of the cultivars over passed $1.5 \mathrm{~m}$ in height after the pruning back of the initial shoot at $50 \mathrm{~cm}$. Lower growth, under $1.5 \mathrm{~m}$ in height, was registered at Mikado/M29C, Flopria/M29C, Bergeron/M29C and Boccuccia Liscia/M29C.

After the second growing season, the most vigorous cultivars were Pisana/M29C and Congat/M29 C, followed by Bergeron, Milord and Medflo, also grafted on Myrobalan 29 C. GF 677 induced a lower growth on Congat than Myrobalan 29C. 

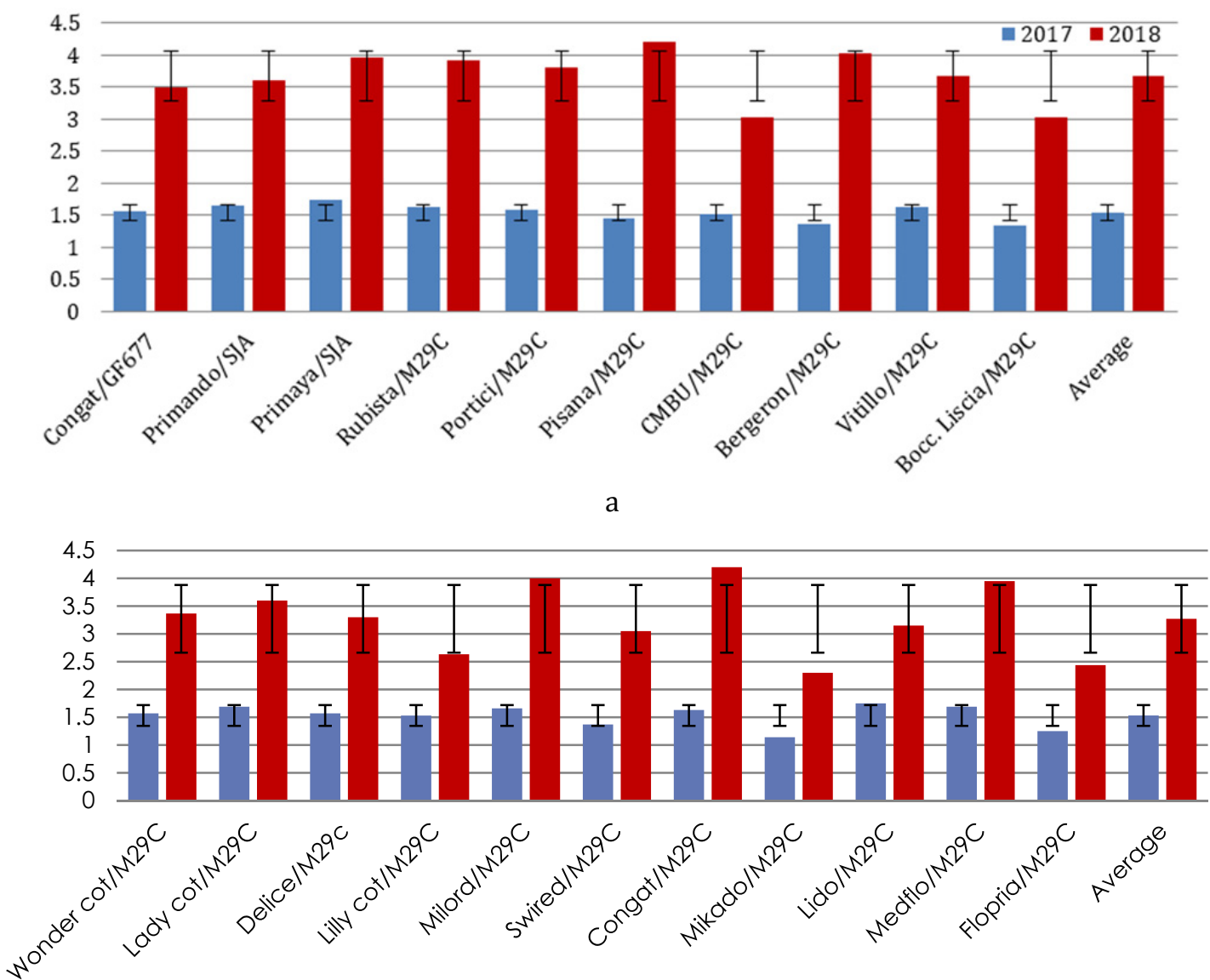

b

* Vertical bars are indicating the standard deviation (SD)

Figure 2 (a, b). Apricot tree height influenced by cultivar and rootstock - Parallel U canopy

After the first growing season, the trees conducted as Trident registered an average height of $1.6 \mathrm{~m}$ (Figure 3). The most vigorous cultivars were Farbali/Saint Julien A, followed by Farclo/SJA, with over $1.75 \mathrm{~m}$ height. The lowest vigour, less that $1.5 \mathrm{~m}$ height, was measured at Farely and Primaya, both grafted on Saint Julien A.

At the end of the second growing season, the most vigorous cultivars, that over passed $3.5 \mathrm{~m}$ in height, were Anegat/M29C and Farclo/SJA. The lowest growth was measured at Fartoly/SJA, Farbela/M29C and Faralia/M29C.

Do to the fact that, at Trident canopy, each tree formed three axes the vigour was distributed in three, the average tree vigour was lower than at Parallel $U$, were the growth vigour was distributed on two axes.

Trunk cross section was also influenced by cultivar, rootstock and canopy, as it is reflected by the Figure $4 \mathrm{a}$ and $\mathrm{b}$ and Figure 5 .

At the end of the first growing year, the trunk cross section varied, for Parallel $U$ canopy, from $2.51 \mathrm{~cm}^{2}$ at Mikado/M29C, the less vigorous cultivar to Lido $\left(11.16 \mathrm{~cm}^{2}\right)$ and Milord $\left(11.05 \mathrm{~cm}^{2}\right)$, the most vigorous cultivars, both grafted on Myrobalan 29C. all cultivars.

In average, during the second growing season, the TCS had a spectacular growth for 


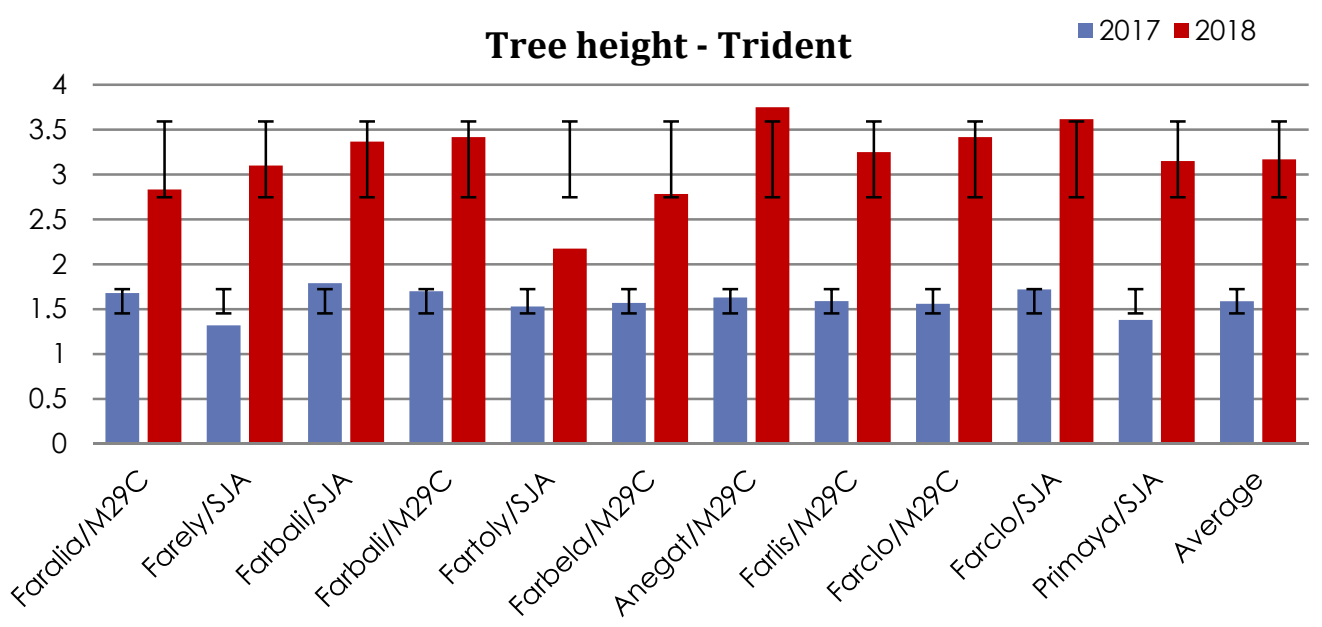

* Vertical bars are indicating the standard deviation (SD)

Figure 3. Apricot tree height influenced by cultivar and rootstock - Trident canopy

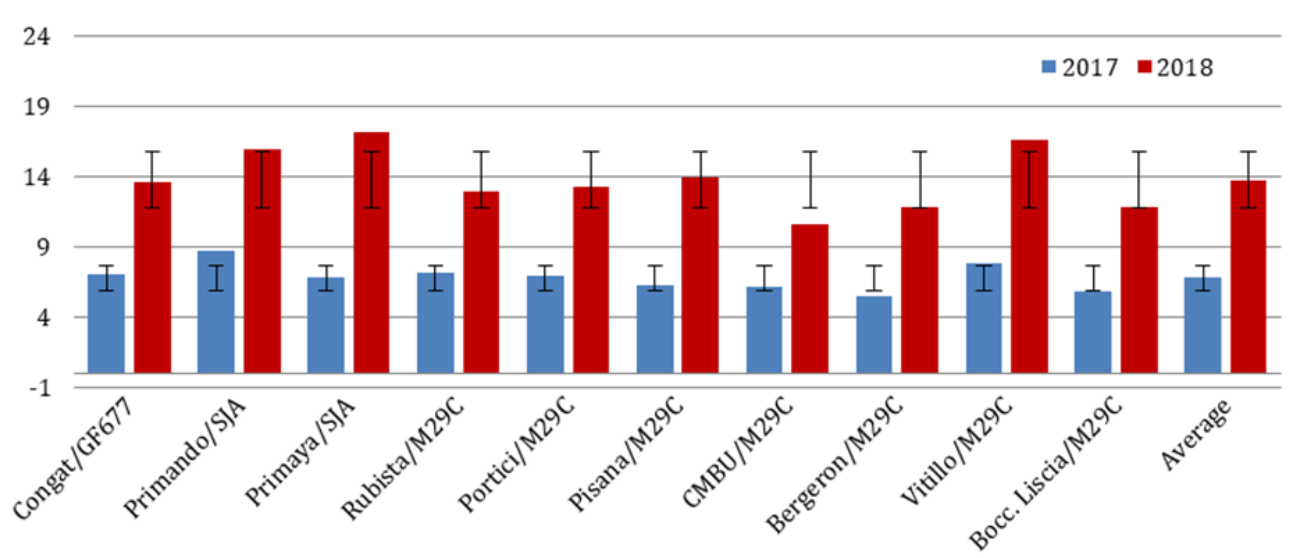

a
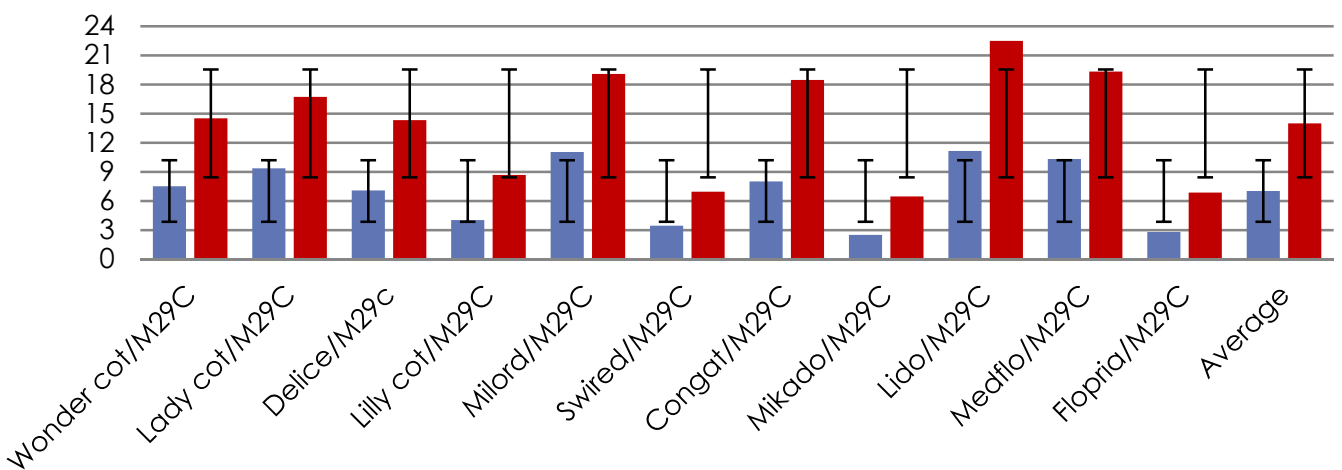

$\mathrm{b}$

* Vertical bars are indicating the standard deviation (SD)

Figure $4(\mathrm{a}, \mathrm{b})$. Apricot trunk cross section $\left(\mathrm{cm}^{2}\right)$ influenced by cultivar and rootstock Parallel U

The highest TCS value was registered at Lido grafted on M29C $\left(22.49 \mathrm{~cm}^{2}\right)$, followed by Medflo (19.53 $\mathrm{cm}^{2}$ ) and Milord (19.09 $\mathrm{cm}^{2}$ ), both grafted on Myrobalan 29C. The smallest 
TCS, was instead measured at Mikado $\left(6.47 \mathrm{~cm}^{2}\right)$ followed by Flopria $\left(6.87 \mathrm{~cm}^{2}\right)$, both grafted on Myrobalan 29C.

The trunk cross section (TCS) at Trident canopy registered higher values at all cultivars and cultivars with an average of $12.72 \mathrm{~cm}^{2}$, in the first growing year and $24.95 \mathrm{~cm}^{2}$, in the second growing year.

The highest TCS value was registered by Farclo, grafted on M29C $\left(33.90 \mathrm{~cm}^{2}\right)$ and the same cultivar, grafted on SJA $\left(31.09 \mathrm{~cm}^{2}\right)$. The smallest TCS value was measured at Fartoly/SJA (19.74 $\left.\mathrm{cm}^{2}\right)$, followed by Primaya/SJA $\left(19.99 \mathrm{~cm}^{2}\right)$.

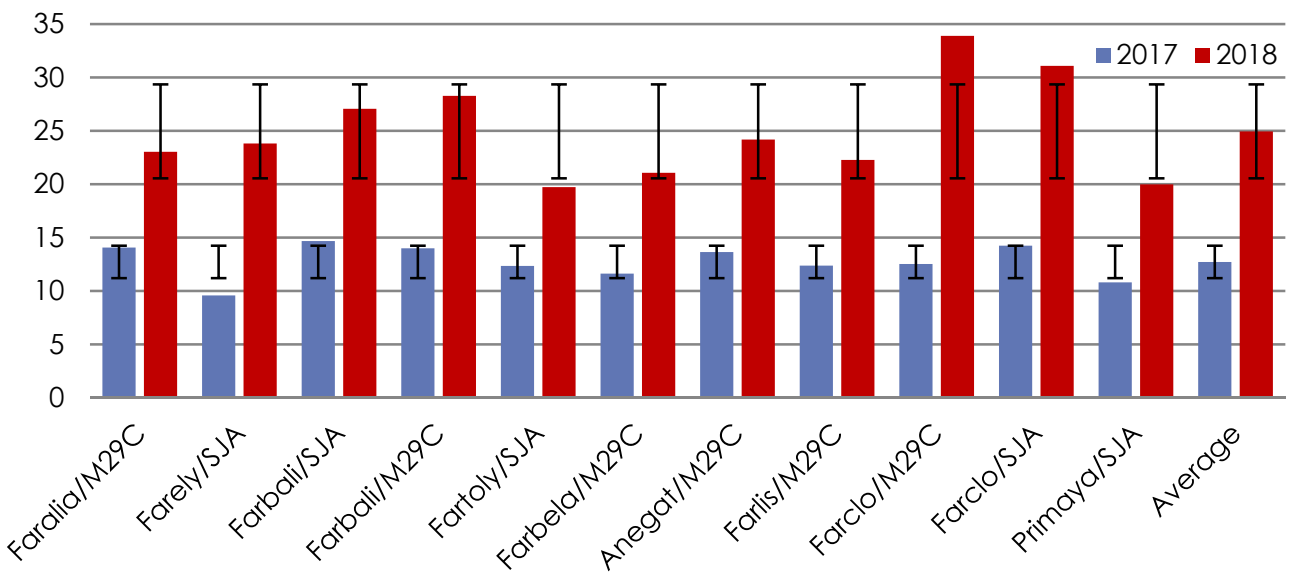

* Vertical bars are indicating the standard deviation (SD)

Figure 5. Apricot trunk cross section $\left(\mathrm{cm}^{2}\right)$ influenced by cultivar and rootstock Trident

By analysing the correlation existing between the trunk cross section and tree height, we found out in the first growing year a high correlation index that varied from 0.77 for Parallel U ( $4.5 \times 1.5 \mathrm{~m}), 0.91$ for Parallel U ( $3.5 \times 2.0 \mathrm{~m})$ to 0.97 for Trident $(3.5 \times 2.0 \mathrm{~m})$. In the second year, the correlation decreased and regression equations are presented in Table 1.

Table 1. Correlation between Trunk Cross Section and Tree Height

\begin{tabular}{|l|c|c|c|l|}
\hline Canopy and planting distances & Year & \multicolumn{1}{|c|}{$\mathrm{R}$} & \multicolumn{1}{|c|}{$\mathrm{R}^{2}$} & \multicolumn{1}{|c|}{ Regression equations } \\
\hline Parallel U (4.5 $1.5 \mathrm{~m})$ & 2017 & 0.77 & 0.57 & $\mathrm{y}=0.1012 \mathrm{x}+0.859$ \\
\cline { 2 - 5 } & 2018 & 0.42 & 0.18 & $\mathrm{~ns}$ \\
\hline \multirow{2}{*}{ Parallel U (3.5 $\mathrm{x} 2.0 \mathrm{~m})$} & 2017 & 0.91 & 0.83 & $\mathrm{y}=0.0539 \mathrm{x}+1.1526$ \\
\cline { 2 - 5 } & 2018 & 0.80 & 0.63 & $\mathrm{y}=0.0872 \mathrm{x}+2.0512$ \\
\hline \multirow{2}{*}{ Trident $(3.5 \times 2.0 \mathrm{~m})$} & 2017 & 0.97 & 0.94 & $\mathrm{y}=0.086 \mathrm{x}+0.4944$ \\
\cline { 2 - 5 } & 2018 & 0.64 & 0.41 & $\mathrm{y}=0.0613 \mathrm{x}+1.6401$ \\
\hline
\end{tabular}

$\mathrm{x}=$ Trunk cross section; $\mathrm{y}=$ Tree height

2. Tree productivity, expressed as $\mathrm{kg} /$ tree and respectively, $\mathrm{t} / \mathrm{ha}$, was influenced by the genotype, rootstock and canopy (Figure $6 \mathrm{a}$ and $\mathrm{b}$ and Figure 7). 


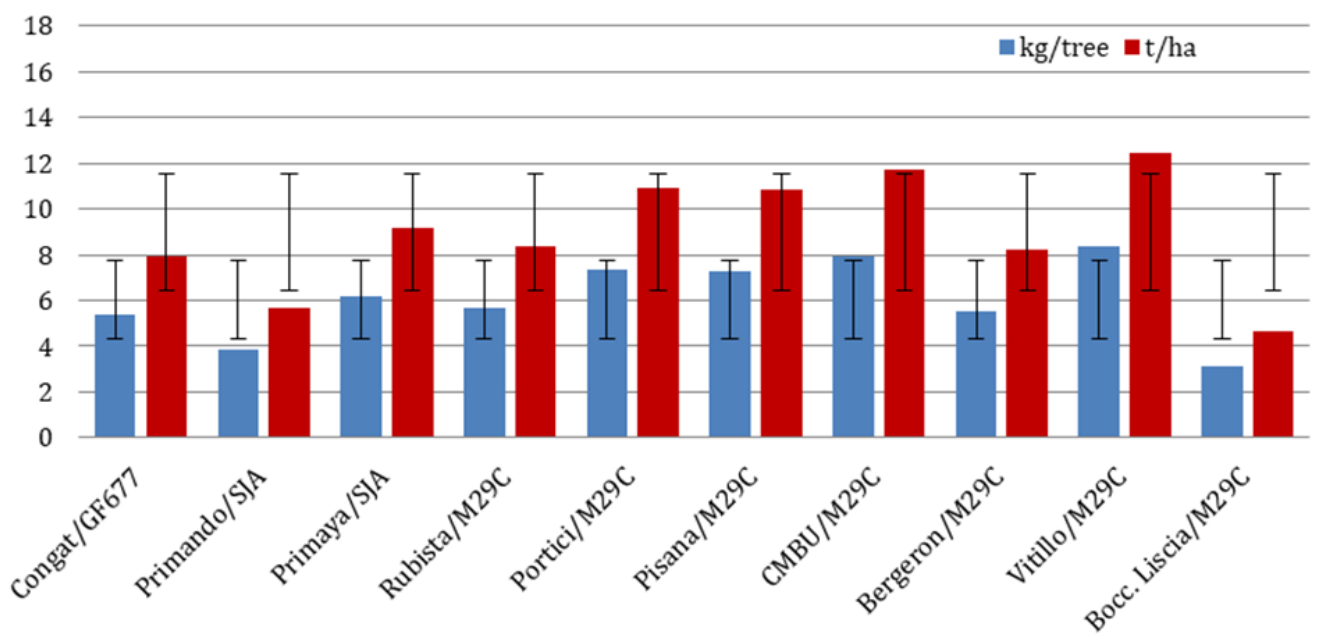

a
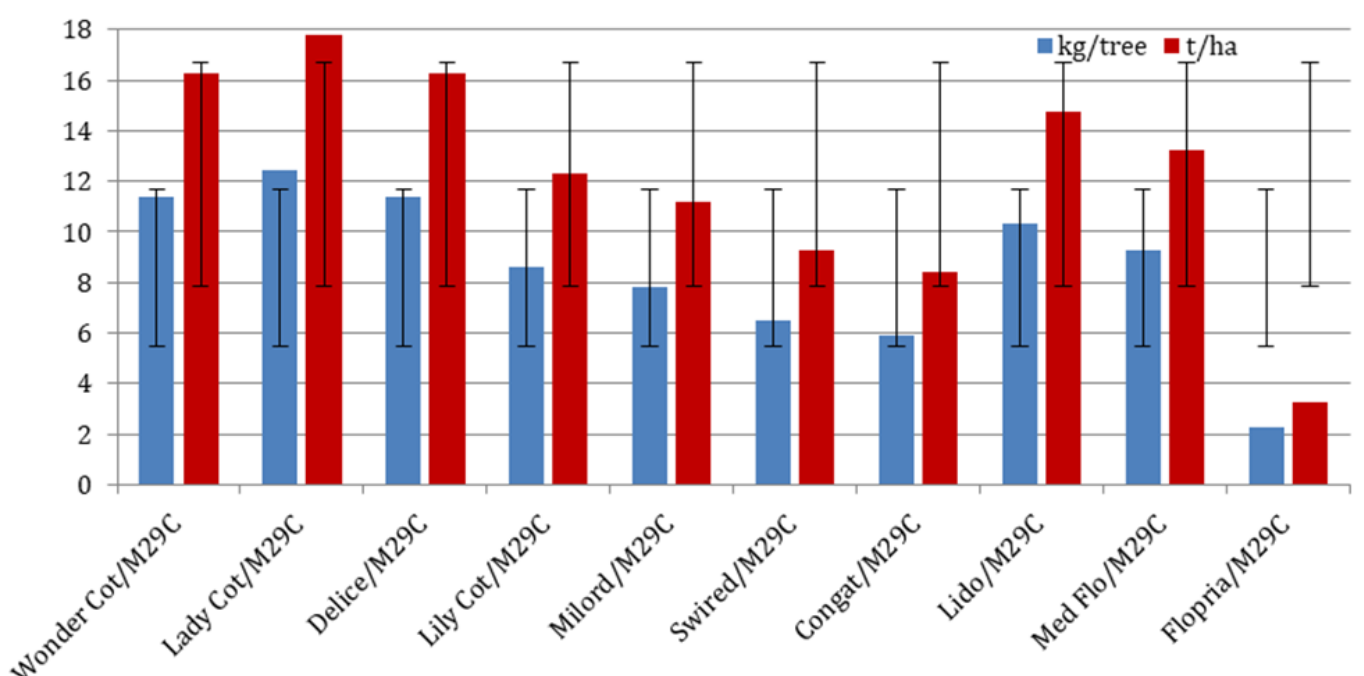

b

* Vertical bars are indicating the standard deviation (SD)

Figure $6(\mathrm{a}, \mathrm{b})$. Apricot productivity $(\mathrm{kg} /$ tree and $\mathrm{t} / \mathrm{ha})$ influenced by cultivar and rootstock Parallel U canopy

When analysing the results of Parallel U canopy, the most productive in the second year after planting, was the cultivar Lady Cot (17.75 t/ha), followed by Wonder Cot (16.25 t/ha) and Delice (16.24 t/ha), all cultivars being grafted on Myrobalan 29C. The lowest yield was registred at Flopria with only $3.25 \mathrm{t} / \mathrm{ha}$ and Boccuccia Liscia (4.68 t/ha).

The cultivars conducted as Trident registered a higher yield comparing with Parallel $\mathrm{U}$, Anegat being on the first place (20.85 t/ha), followed by Faralia (17.62 t/ha). Lowest yield was produced by Farclo (7.79 t/ha).

The productivity index (not presented in this paper) expressed as $\mathrm{kg} / \mathrm{cm}^{2} \mathrm{TCS}$, varied a lot with the cultivar between 0.16 (Farclo/M29C) and 0.91 (Lily Cot/M29C). 


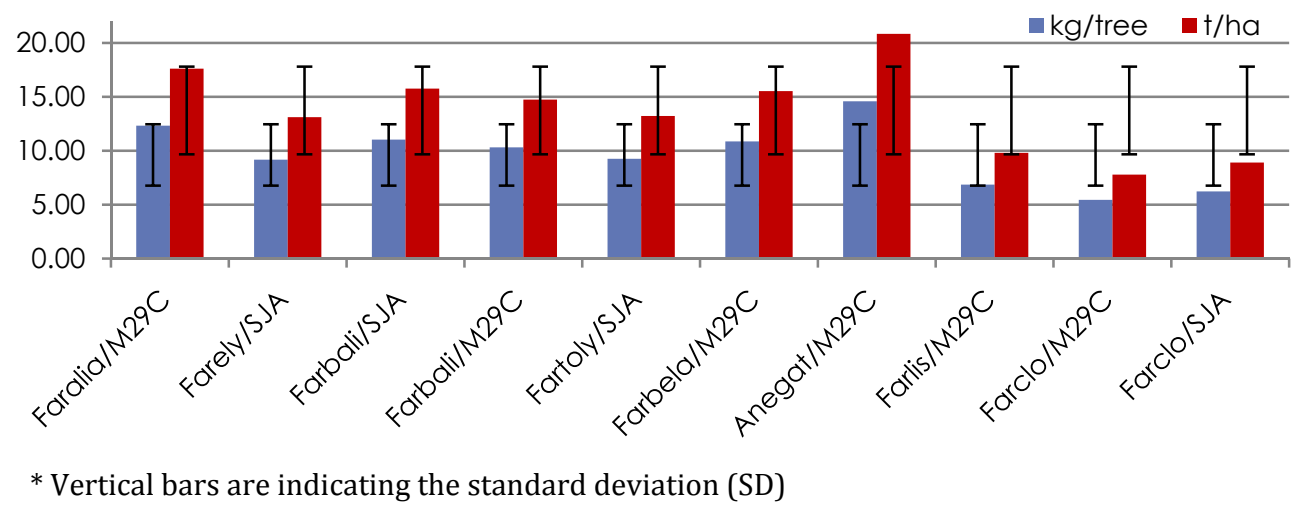

Figure 7. Apricot productivity (kg/tree and t/ha) influenced by cultivar and rootstock - Trident

\section{CONCLUSIONS}

The new tested apricot cultivars showed in general a good adaptation in the first two years of vegetation, by realising a strong growth and reaching the planned height, with a slight delay at Trident canopy, were the tree vigour was split between the three axes.

There were registered important differences in vigour between studied cultivars while, generally, Myrobalan 29C induced a superior vigour.

Even at the end of the first growing year, the trunk cross section(TCS)was quite similar, in the second year, each cultivar started to expressed its vigour. In the first growing year strong correlation was found between TCS and tree height.

Most of the studied cultivars expressed their precocity and high productivity and produced, in the second year after planting, a top yield of $20.85 \mathrm{t} / \mathrm{ha}$ (Anegat/M29C). Under Trident, the first yield was higher, probably because of a denser canopy permanent structure realized by the three axes, in comparison to only two axes in Parallel U.

\section{REFERENCES}

1. Asma, B.M. Breeding program for Plum Pox Virus resistance in turkey: Preliminary results. Acta Hortic. (ISHS) 2012, 966, 285-290.

2. Audergon J.M., A. Blanc, G. Clauzel, C. Pitiot, B. Gouble, M. Grotte, M. Reich and S. Bureau (2010). 'Rubisco'® a new French series of apricot. Acta Hortic. 862, 399-404. DOI: 10.17660/ActaHortic.2010.862.61.

3. Audergon, J.M.; Blanc, A.; Gilles, F.; Clauzel, G.; Broquaire, J.M.; Gouble, B.; Grotte, M.; Reich, M.; Bureau, S.; Frémondière, G.; Pitiot, C., 2012, An integrated apricot breeding program in France joining cep innovation - centrex and inra. Acta Hortic. (ISHS) 966, 17-21.

4. Auvinet, C., Blanc, A., Gilles, F., Clauzel, G., Hostalnou, E., Courthieu, N., Roch, G., Gouble, B., Bureau, S., Pitiot, C. and Audergon, J.M. (2020). Selections issued from CEP INNOVATION, CENTREX and INRA: apricot breeding program in France. Acta Hortic. 1290, 31-34.DOI: 10.17660/ActaHortic.2020.1290.6

5. Bassi, D. and Foschi, S. (2020). Raising the standards in breeding apricots at MAS.PES, Italy. Acta Hortic. 1290, 27-30 DOI: 10.17660/ActaHortic.2020.1290.5.

6. Bălan V., Topor E., Tudor V., Stănică, F., Hoza D. Chira A., Chira L., Marin I., Nistor E., Asănică A., 2008, Caisul şi caisele (Apricot and apricot fruits). Editura Ceres, București, ISBN 978-973-40-0797-4, pg. 686.

7. Dejampour, J. (2012). New Apricots from a Breeding Program in Sahand Horticultural Research Station. Acta Hortic. 966, 75-79, DOI: 10.17660/ActaHortic.2012.966.11.

8. Dorigoni, A., Lezzer, P., Dallabetta, N., Serra, S. and Musacchi, S. (2011). Bi-axis: an alternative to slender spindle for apple orchards. Acta Hortic. 903, 581-588. DOI: 10.17660/ActaHortic.2011.903.80.

9. Duval, H., Masse, M., Jay, M. and Loquet, B. (2012). Results of French Apricot Rootstock Trials. Acta Hortic. 966, 37-41. DOI: 10.17660/ActaHortic.2012.966.4.

10. Egea, J.; Rubio, M.; Dicenta, F.; Ruiz, D. 2012,New early ripening, sharka resistant apricot cultivars at cebas-csic (Murcia, Spain). Acta Hortic. (ISHS), 966, 63-66.

11. Gorina, V.M., Korzin, V., Mitrofanova, O.V. and Mitrofanova, I.V. (2020). Perspectives of apricot breeding in the Nikita Botanical Gardens. Acta Hortic. 1290, 5-12. DOI: 10.17660/ActaHortic.2020.1290.2. 
12. Gouble, B., Scofield, C., McGlone, A., Boldingh, H., Clark, C., Audergon, J.M., Bureau, S. and Stanley, J. (2020). Evaluation of apricot fruit quality diversity in two countries, France and New Zealand. Acta Hortic. 1290, 147-154. DOI: 10.17660/ActaHortic.2020.1290.27.

13. Krška, B., Gogolková, K., Ondrášek, I. and Dokoupil, L. (2012). Preliminary evaluation of basic biological traits of apricots on selected rootstocks. Acta Hortic. 966, 183-187. DOI: 10.17660/ActaHortic.2012.966.28

14. Krška B., Vachůn Z. 2016, Apricot Breeding at the Faculty of Horticulture in Lednice, Agronomy 6 (2), 27; doi:10.3390/agronomy6020027.

15. Lauri, P.E., Hucbourg, B., Ramonguilhem, M. and Méry, D. (2011). An architectural-based tree training and pruning - identification of key features in the apple. Acta Hortic. 903, 589-596. D0I: 10.17660/ActaHortic.2011.903.81.

16. Liu, W., Liu, N., Zhang, Y., Yu, X., Sun, M., Xu, M., Zhang, Q. and Liu, S. (2012). Apricot cultivar evolution and breeding program in China. Acta Hortic. 966, 223-228. DOI: 10.17660/ActaHortic.2012.966.35.

17. Matei T., Stănică F., Gâlă R.A., 2013, The Effect of Planting System on Canopy Architecture of Some New Peach Cultivars Cultivated in the Southern Part of Romania, Second Balkan Symposium on Fruit Growing, ISHS, ICDP Pitești, September 5-7. Acta Hort. (ISHS) 981:289-293.

18. Meland, M. 2001. Early performance of European plum high density production systems. Proc. VIIth IS on Orch. \& Plant. Syst. Acta Hort. 557: 265-273.

19. Milatović, D., Durović, D., Nikolić, D. and Zec, G. (2012). Improvement of apricot cultivar assortment in Serbia. Acta Hortic. 966, 131-135. DOI: 10.17660/ActaHortic.2012.966.20,

20. Musacchi, S. 2008. Bibaum ${ }^{\circledR}$ : a new Training system for pear orchards. Acta Hort. 800: 763-768.

21. Negru Ion, 2019, Effect of tree conduce on the precocity, yield and fruit quality to apricot. Analele Universității din Craiova, seria Biologie, Horticultură, Tehnologia Prelucrării Produselor Agricole, Ingineria Mediului.

22. Negru I., Peșteanu A., 2019, Productivity of apricot ochard by the method of conducting the crown in the period of growing and fructification of the trees.Lucrări Ştiinţifice, Seria Horticultură - Iași, Anul LXII Vol 62 - nr. 1 - 2019.

23. Neri, D., Morini, F., Massetani, F. and Pirazzini, P. 2010. Pruning: how to manage shoot growth. Proc. XIVth IS Apricot Breeding and Culture. Acta Hort. 862: 355-363.

24. Nesheva, M., Bozhkova, V. and Milusheva, S. (2020). Some results of the apricot breeding program in Fruit Growing Institute - Plovdiv, Bulgaria. Acta Hortic. 1290, 1-4. DOI: 10.17660/ActaHortic.2020.1290.1

25. Oprița, V.A., Gavăt, C. and Caplan, I. (2020). Improvement of apricot cultivars assortment in Romania. Acta Hortic. 1290, 179-184. DOI: 10.17660/ActaHortic.2020.1290.31.

26. Palmer, J.W. (2011). Changing concepts of efficiency in orchard systems. Acta Hortic. 903, 41-49. DOI: 10.17660/ActaHortic.2011.903.1.

27. Robinson, T.L., Hoying, S.A. and Reginato, G.H. 2011. The tall spindle planting system: principles and performance. Proc. IXth IS on Orchard Systems. Acta Hort. 903: 571-579.

28. Suran, P. and Skřivanová, A. (2020). Apricot breeding program in Holovousy (CZ): new selection. Acta Hortic. 1290, 35-40 DOI: 10.17660/ActaHortic.2020.1290.7.

29. Stănică F. 2008, Principalele forme de coroană şi tehnica formării lor. Tăierile la cais. (Most popular tree canopies and their formation technique. Apricot pruning) in „Caisul şi caisele” (Apricot and apricot fruits). Bălan Viorica et al., Editura Ceres, București, ISBN 978-973-40-0797-4, pg. 686

30. Stănică F., Armeanu I., Dumitrașcu M., Peticilă G.A, 2010, Influence of the Climate Conditions on Apricot Floral Biology in București Area, XIV ISHS International Symposium on Apricot Breeding and Culture. Matera, Italia, Acta Hort. 862, pp. 283-291, http://www.actahort.org/books/862/862_44.htm.

31. Stănică F., Peticilă A., Dumitrașcu M., Matei T., Gâlă R.A., 2012, Influence of the planting system on peach tree growth and productivity, ISHS International Horticultural Congress, Lisabona, Portugalia. Acta Hort. (ISHS) 940: 293-299.

32. Stănică F., Eremia A., 2014, Behaviour of some new apricot cultivars under the parallel trident planting system. 10th ISHS International Symposium on Orchard Systems, Stellenbosch Univ. (3-6 Dec.) Acta Hort. (ISHS) 1058:129-136.

33. Stănică F. 2019, New tendencies in fruit trees training and orchard planting systems. Scientific Papers. Series B, Horticulture, Vol. LXIII, Issue 2, Print ISSN 2285-5653, 25-34.

34. Tabakov, S.G. and Yordanov, A.I. (2012). Orchard performance of Hungarian apricot cultivar on eleven rootstocks in Central South Bulgaria conditions. Acta Hortic. 966, 241-247. DOI: 10.17660/ActaHortic.2012.966.38.

35. Topor E., R. Vasilescu, V. Balan and V. Tudor (2010). Apricot breeding programme for late and very late ripening period in Romania. Acta Hortic. 862, 137-142. DOI: 10.17660/ActaHortic.2010.862.21

36. Xue, X.M., Wang, J.Z., Han, X.P. and Chen, R. (2020). A new late ripening apricot cultivar - 'Longjinmi'. Acta Hortic. 1290, 185-190, DOI: 10.17660/ActaHortic.2020.1290.32. 